\title{
Solid inoculants as a practice for bioaugmentation to enhance bioremediation of hydrocarbon contaminated areas
}

\author{
Haoshuai $\mathrm{Li}^{1}$, Mutai Bao ${ }^{1}$, Yang $\mathrm{Li}^{1}$, and Shudong $\mathrm{Li}^{1}$ \\ ${ }^{1}$ Ocean University of China
}

May 5, 2020

\begin{abstract}
Vacuum freeze-drying is a scientifically advanced method to prepare solid inoculants from oil degrading bacterium. The introduction of oil-degrading microbes or bioaugmentation can be an efficient way to bioremediate oil spills in marine areas, where oil-degrading bacteria are deficient. The purpose of this study is to evaluate the potential use of solid inoculants of LZ-2 bacteria to enhance the degradation rate of crude oil. In this study, response surface methodology (RSM) was incorporated into the experimental design to optimize a response, which is influenced by different protectants. Our results showed that five factors have interactive and synergistic protective effects on the growth of LZ-2. Optimal growth of freeze-dried LZ-2 (63.8\%) was observed with a $10.5 \%$ solution of skim milk supplemented with $14.3 \%$ sucrose, $14.4 \%$ of trehalose, $4.9 \%$ of glycerin and $14.7 \%$ of $\beta$-cyclodextrin. The culture grew in medium containing crude oil $(3 \mathrm{~g} / \mathrm{L})$ at $37^{\circ} \mathrm{C}$ at $150 \mathrm{rpm}$ for 30 days, GC and GC-MS analysis showed biodegradation of 44.2 and $21.6 \%$ for total saturate and aromatic hydrocarbons respectively. These results indicated that the solid inoculants of LZ-2 bacteria had the potential to be used for ex-situ bioremediation of hydrocarbon pollutants associated with crude oil.
\end{abstract}

\section{Hosted file}

Manuscript.docx available at https://authorea.com/users/298873/articles/428238-solidinoculants-as-a-practice-for-bioaugmentation-to-enhance-bioremediation-of-hydrocarboncontaminated-areas 